\title{
Gambaran Kontaminasi Bakteri pada Sirkuit Pernapasan Anestesi di Ruang Operasi Rumah Sakit Dr. Hasan Sadikin Bandung pada Bulan Agustus 2015
}

\author{
Suryadi, ${ }^{1}$ Iwan Fuadi, ${ }^{2}$ Ruli Herman Sitanggang ${ }^{2}$ \\ ${ }^{1}$ Bagian Anestesi dan Terapi Intensif RSUD Balaraja Banten, \\ ${ }^{2}$ Departemen Anestesiologi dan Terapi Intensif \\ Fakultas Kedokteran Universitas Padjadjaran/Rumah Sakit Dr. Hasan Sadikin Bandung
}

\begin{abstract}
Abstrak
Rumah Sakit Dr. Hasan Sadikin Bandung memakai sirkuit pernapasan dalam melakukan tindakan anestesi di ruang operasi. Sirkuit tersebut digunakan berulang dan diganti setiap 24 jam. Penelitian ini dilakukan untuk mengetahui gambaran kontaminasi bakteri pada sirkuit pernapasan anestesi. Penelitian dilakukan dengan metode deskriptif observasional secara cross-sectional. Sebanyak 102 sampel dari 51 sirkuit pernapasan anestesi diperiksa kultur bakteri sebelum dan sesudah digunakan pada ruang operasi Rumah Sakit Dr. Hasan Sadikin Bandung selama 3 hari pada bulan Agustus 2015. Pengambilan sampel dilakukan dengan metode apus pada konektor $Y$ sirkuit pernapasan anestesi sebelum dan sesudah digunakan dalam 24 jam. Hasil penelitian ini menunjukkan tidak ada kontaminasi bakteri pada sirkuit pernapasan anestesi sebelum digunakan pada ruang operasi Rumah Sakit Dr. Hasan Sadikin Bandung. Kontaminasi bakteri pada sirkuit pernapasan anestesi sesudah digunakan pada ruang operasi Rumah Sakit Dr. Hasan Sadikin Bandung adalah 25,49\%. Gambaran pola bakteri yang teridentifikasi adalah bakteri Micrococcus spp., Bacillus spp., Streptococcus viridans, Serratia marcescens, Staphylococcus aureus, Staphylococcus epidermidis, Staphylococcus hominis, dan Staphylococcus saprophyticus. Simpulan penelitian ini adalah tidak ditemukan kontaminasi bakteri pada sirkuit pernapasan anestesi sebelum digunakan dan ditemukan kontaminasi bakteri pada sirkuit pernapasan anestesi sesudah digunakan pada ruang operasi Rumah Sakit Dr. Hasan Sadikin Bandung.
\end{abstract}

Kata kunci: Gambaran pola bakteri, kontaminasi bakteri, sirkuit pernapasan anestesi

\section{Description of Bacteria Contamination in Anesthesia Breathing Circuit in Operating Room Dr. Hasan Sadikin Bandung General Hospital in August 2015}

\begin{abstract}
Breathing circuits have been used repeatedly to perform anesthesia in the operating theater of Dr. Hasan Sadikin General Hospital with a replacement interval of every 24 hours. This study was conducted to determine the contamination of bacteria in the anesthesia breathing circuits. This was an observational descriptive cross-sectional study on 102 samples from 51 anesthesia breathing circuits. These samples were cultured before and after the use of breathing circuit in the operating room of Dr. Hasan Sadikin General Hospital for 3 days in August 2015. Sampling was performed using swab method at the Y connector of anesthesia breathing circuit before and after use within a period of 24 hours. The results showed that no bacterial contamination was found in the anesthesia breathing circuit before use in the operating theatre of Dr. Hasan Sadikin Hospital Bandung. Bacterial contamination of anesthesia breathing circuit after use was $25.49 \%$. The bacteria identified were Micrococcus spp., Bacillus spp., Streptococcus viridans, Serratia marcescens, Staphylococcus aureus, Staphylococcus epidermidis, Staphylococcus hominis and Staphylococcus saprophyticus. It is concluded that no bacterial contamination of anesthesia breathing circuit before use; however, bacterial contamination was found after the use of anesthesia breathing circuits in the operating theatre of Dr. Hasan Sadikin General Hospital Bandung.
\end{abstract}

Key words: Anesthesia breathing circuits, bacterial contamination, description of the bacteria Korespondensi: Suryadi, dr., SpAn, Bagian Anestesi dan Terapi Intensif RSUD Balaraja Banten, Jl. Rumah Sakit No. 88 Desa Tobat Kec. BalarajaKab. Tanggerang Prov. Banten, Tlpn. 021-29508250 Mobile 081220221912,Email sury_persona@ yahoo.com 


\section{Pendahuluan}

Sirkuit pernapasan anestesi merupakan alat yang menghubungkan antara pasien dan mesin anestesi. Sirkuit pernapasan anestesi yang paling sering digunakan dalam mesin anestesi merupakan sistem sirkuler yang seringkali digunakan berulang pada pasien yang berbeda. Penggunaan sirkuit pernapasan anestesi secara berulang bertujuan mengurangi biaya dan limbah rumah sakit. Namun, hal ini harus mempertimbangkan keselamatan pasien. ${ }^{1}$

Pemakaian sirkuit pernapasan anestesi biasanya diganti pada frekuensi tertentu. Pergantian sirkuit pernapasan di Inggris dan Jerman dilakukan tiap 24 jam dengan memakai filter baru untuk setiap pasien. Di Australia, sirkuit pernapasan anestesi diganti setiap minggu, namun hal ini tidak direkomendasikan oleh Centers for Disease Control (CDC) Amerika. Mereka merekomendasikan pergantian sirkuit pernapasan anestesi untuk setiap pasien yang dianestesi. ${ }^{2-6}$ Rumah Sakit Dr. Hasan Sadikin (RSHS) Bandung memakai sirkuit pernapasan anestesi baru tanpa menggunakan filter dan dilakukan pergantian setiap 24 jam.

Sirkuit pernapasan anestesi menyediakan suasana media kultur yang ideal untuk pertumbuhan mikro-organisme. Hal ini dapat terjadi karena reaksi kimia antara karbon dioksida dan soda lime di dalam sirkuit yang menghasilkan air dan panas sehingga lingkungan menjadi lembap dan hangat. Air juga dihasilkan dari penguapan pasien pada saat fase ekspirasi. ${ }^{7}$

Kontaminasi bakteri pada mesin dan sirkuit pernapasan anestesi telah banyak diteliti. Beberapa hasil penelitian menemukan bakteri, jamur, dan virus. ${ }^{7}$ Banyak penelitian yang telah dilakukan untuk mengetahui kontaminasi bakteri pada pemakaian sirkuit pernapasan anestesi yang berulang. Kontaminasi terhadap sirkuit pernapasan anestesi setelah digunakan berkisar $8-13 \%{ }^{8}$

Sumber patogen pada sirkuit pernapasan dapat berasal dari pasien yang dilepaskan ke lingkungan sekitar atau ditransmisi melalui tenaga medis. Sirkuit pernapasan anestesi dapat terkontaminasi setelah digunakan oleh pasien. Kontaminasi tersebut lebih banyak ditemukan pada sirkuit yang berhubungan langsung dengan pasien. ${ }^{1,8}$

Infeksi silang dapat terjadi antara pasien yang terkontaminasi dan sirkuit pernapasan yang terinfeksi. Infeksi tersebut terjadi akibat perpindahan cairan antara sirkuit dan pasien. Infeksi ini dapat menyebabkan morbiditas dan mortalitas. ${ }^{9,10}$ Kontaminasi sirkuit pernapasan anestesi inilah yang menjadi penyebab infeksi saluran napas atas dan paru pada pasien yang menjalani anestesi umum. ${ }^{11,12}$

Tujuan penelitian ini adalah mengetahui gambaran kontaminasi sirkuit pernapasan anestesi sebelum dan sesudah digunakan pada ruang operasi Rumah Sakit Dr. Hasan Sadikin Bandung serta jenis bakterinya.

\section{Subjek dan Metode}

Penelitian ini merupakan penelitian deskriptif observasional dan merupakan studi crosssectional yang dilakukan sesudah mendapat persetujuan dari Komite Etik Penelitian Kesehatan Fakultas Kedokteran Universitas Padjadjaran/Rumah Sakit Dr. Hasan Sadikin Bandung. Penelitian dilakukan pada bulan Agustus 2015 dengan kriteria inklusi adalah sirkuit pernapasan anestesi baru yang belum digunakan dan sesudah digunakan dalam 24 jam di ruang operasi RSHS Bandung. Sampel penelitian diambil dari sirkuit pernapasan anestesi saat sebelum dan sesudah digunakan dalam 24 jam di ruang operasi RSHS selama 3 hari pada tanggal 13-14 Agustus 2015. Sampel yang diteliti sebanyak 102 sampel pada 51 buah sirkuit pernapasan anestesi.

Penelitian dilakukan dengan melakukan kultur bakteri memakai metode pengapusan mengunakan kapas lidisteril pada bagian dalam konektor Y. Semua bakteri yang teridentifikasi pada kultur dicatat dan dilaporkan berdasar atas sampel pemeriksaan.

Analisis data dilakukan untuk memberikan gambaran proporsi tiap-tiap variabel. Data kategorik disajikan secara deskriptif. Data numerik disajikan berupa mean, minimum dan maksimum data, standar deviasi, range, dan juga median. Data yang diperoleh dicatat 


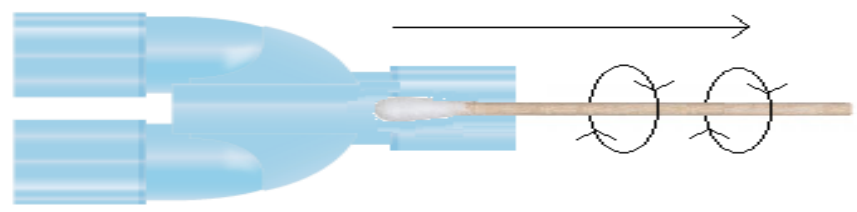

Gambar 1 Metode Apus pada Konektor Y

Dikutip dari: Flexicare ${ }^{19}$

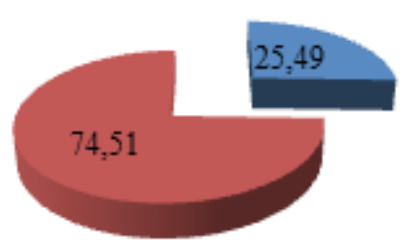

- Kontaminasi sirkuit pernapasan (13 sampel)

- Steril (38 sampel)

Gambar 2 Persentase Kontaminasi Bakteri pada Sirkuit Pernapasan Anestesi Sesudah Digunakan pada Ruang Operasi RSHS Bandung

di dalam formulir khusus, kemudian diolah menggunakan program statistical package for the social science (SPSS) versi 21.0 for windows.

\section{Hasil}

Penelitian ini tidak menemukan kontaminasi bakteri di sirkuit pernapasan anestesi sebelum digunakan pada ruang operasi Rumah Sakit Dr. Hasan Sadikin Bandung. Berdasar atas penelitian ini, kontaminasi sirkuit pernapasan anestesi sesudah digunakan adalah 13 dari 51 (25,49\%). Kontaminasi bakteri pada sirkuit pernapasan yang sudah digunakan di ruang operasi gawat darurat lebih besar dibanding dengan ruang elektif lantai 3 dan lantai 4 (Tabel 1).

Pada penelitian ini didapatkan gambaran kontaminasi bakteri pada sirkuit pernapasan anestesi sesudah digunakan di ruang operasi
RSHS Bandung (Tabel 2). Pada penelitian ini tidak ditemukan bakteri patogen.

Dari penelitian ini didapatkan kontaminasi bakteri dengan jumlah penggunaan sirkuit 3 kali lebih tinggi dibanding dengan penggunaan sirkuit 2 kali dan 1 kali. Berdasar atas hasil uji Kolmogorv Smirnov, didapat perbedaan yang tidak bermakna dengan nilai $\mathrm{p}=0,774(\mathrm{p}>0,05$; Tabel 3).

Kontaminasi bakteri pada sirkuit yang digunakan $>500$ menit lebih tinggi dibanding dengan lama penggunaan sirkuit 250-500 menit dan <250 menit. Berdasar atas hasil uji Kolmogorv Smirnov didapatkan perbedaan bermakna dengan nilai $\mathrm{p}<0,05$ (Tabel 4).

\section{Pembahasan}

Penelitian dilakukan pada 102 sampel dari 51 sirkuit pernapasan anestesi sebelum dan

Tabel 1 Gambaran Kontaminasi Bakteri pada Sirkuit Pernapasan Anestesi Sesudah Digunakan berdasar atas Ruang Operasi RSHS Bandung

\begin{tabular}{lcc}
\hline \multicolumn{1}{c}{ Ruang Operasi } & Jumlah Sampel & Sirkuit Terkontaminasi \\
\hline Gawat Darurat & 6 & 3 \\
Ruang Elektif Lantai 3 & 27 & 8 \\
Ruang Elektif Lantai 4 & 18 & 2 \\
\hline
\end{tabular}


Tabel 2 Persentase Bakteri yang Ditemukan pada Sirkuit Pernapasan Anestesi Sesudah Digunakan di Ruang Operasi RSHS Bandung

\begin{tabular}{lc}
\hline \multicolumn{1}{c}{ Jenis Kuman } & $\begin{array}{c}\text { Jumlah } \\
\text { Sirkuit } \\
\text { Terkontaminasi }\end{array}$ \\
\hline Micrococcus spp. & 4 \\
Staphylococcus epidermidis & 3 \\
Bacillus spp. & 1 \\
Stapylococcus hominis & 1 \\
Streptococcus viridans & 1 \\
Serratia marcescens & 1 \\
Stapylococcus aureus + & 1 \\
Staphylococcus saprophyticus & \\
Streptococcus viridans + & 1 \\
Bacillus spp. & \\
\hline
\end{tabular}

sesudah digunakan di ruang operasi RSHS Bandung selama 3 hari pada bulan Agustus 2015. Dari 51 sirkuit pernapasan anestesi yang diperiksa sebelum digunakan tidak ditemukan kontaminasi bakteri. Hal ini disebabkan oleh sirkuit tersebut merupakan sirkuit pernapasan anestesi baru dan masih kemasan steril dari produsen.

Penelitian ini menemukan kontaminasi bakteri di sirkuit pernapasan anestesi sesudah digunakan sebanyak 13 dari 51 sampel yang diperiksa. Tingkat kontaminasi ini didapatkan lebih tinggi bila dibanding dengan penelitian sebelumnya dengan kontaminasi berkisar 8-13\%. Hal ini dikarenakan filter sirkuit pernapasan pada penelitian tersebut tidak digunakan berulang. ${ }^{3,8}$

Kejadian kontaminasi bakteri pada sirkuit pernapasan anestesi dipengaruhi oleh banyak faktor antara lain jumlah bakteri, virulensi
Tabel 3 Perbandingan Proporsi

Kontaminasi Bakteri pada Sirkuit

Pernapasan Anestesi berdasar atas

Kelompok Jumlah Penggunaan

Sirkuit

\begin{tabular}{cccc}
\hline $\begin{array}{c}\text { Jumlah } \\
\text { Operasi }\end{array}$ & $\begin{array}{c}\text { Jumlah } \\
\text { Sampel }\end{array}$ & $\begin{array}{c}\text { Sirkuit } \\
\text { Terkontaminasi }\end{array}$ & $\begin{array}{c}\text { Nilai } \\
\mathbf{p}\end{array}$ \\
\hline 1 & 12 & 1 & \\
2 & 29 & 8 & 0,774 \\
$\geq 3$ & 10 & 4 & \\
\hline
\end{tabular}

Keterangan: nilai p dihitung berdasarkan uji Kolmogorov Smirnov, $\mathrm{p}>0,05=$ tidak bermakna.

dan resistensi bakteri, muatan listrik dari bakteri dan aerosol, ukuran dan distribusi partikel, aliran gas, volume tidal, laju inspirasi, serta frekuensi dan lama pemakaian sirkuit pernapasan anestesi. ${ }^{13}$ Penelitian ini hanya meneliti faktor frekuensi dan lama pemakaian sirkuit, sedangkan faktor lain tidak diteliti karena kesulitan dalam memperoleh data.

Pada penelitian ini didapatkan kontaminasi bakteri pada sirkuit pernapasan di ruang gawat darurat sebesar 3 dari 6 , di ruang operasi elektif lantai 3 sebanyak 8 dari 27, dan di ruang operasi elektif lantai 4 sebesar 2 dari 18 (Tabel 1). Kontaminasi sirkuit pernapasan anestesi di ruang operasi gawat darurat lebih tinggi dibanding dengan ruang operasi elektif lantai 3 dan 4 yang disebabkan oleh penggunaan sirkuit pernapasan anestesi di ruang operasi gawat darurat lebih lama dan lebih banyak jumlah operasi dibanding dengan ruang elektif lantai 3 dan $4 .{ }^{13}$ Demikian juga pergantian petugas ruang operasi lebih sering dibanding dengan petugas ruang operasi elektif.

Pada penelitian ini didapatkan gambaran

Tabel 4 Perbandingan Proporsi Kontaminasi Bakteri pada Sirkuit Pernapasan Anestesi berdasar atas Lama Penggunaan Sirkuit

\begin{tabular}{cccc}
\hline Lama Penggunaan (menit) & Jumlah Sampel & Sirkuit Terkontaminasi & Nilai p \\
\hline$<250$ & 15 & 1 & \\
$250-500$ & 16 & 3 & 0,002 \\
$>500$ & 20 & 9 & \\
\hline
\end{tabular}

Keterangan: nilai $\mathrm{p}$ dihitung berdasarkan uji Kolmogorov Smirnov, $\mathrm{p}<0,05=$ bermakna 
kontaminasi sirkuit oleh bakteri Micrococcus spp., Bacillus spp., Streptococcus viridans, Serratia marcescens, Staphylococcus aureus, Staphylococcus epidermidis, dan Staphylococcus hominis (Tabel 2). Secara umum, bakteri di atas merupakan flora normal pada kulit dan saluran napas manusia. Pada penelitian ini tidak didapatkan bakteri patogen. ${ }^{9}$

Beberapa bakteri tersebut sesuai dengan peta bakteri yang diisolasi di Central Operating Theater (COT) Rumah Sakit Dr. Hasan Sadikin Bandung periode Juli-Desember 2013 seperti Staphylococcus aureus dan Staphylococcus epidermidis yang diisolasi dari cairan tubuh, Streptococcus viridans diisolasi dari cairan tubuh dan darah, serta Serratia marcescens diisolasi dari sputum. ${ }^{14}$

Berdasar atas penelitian ini didapatkan peningkatan kontaminasi sirkuit pernapasan anestesi yang diperiksa setelah 24 jam pada sirkuit yang digunakan berulang-ulang (Tabel 3). Kontaminasi tersebut biasanya berasal dari flora normal kulit dan saluran napas pasien, pegawai ruang operasi, atau berasal dari lingkungan ruang operasi. Peningkatan jumlah penggunaan sirkuit pernapasan anestesi secara berulang membuat sirkuit pernapasan anestesi lebih sering kontak dengan pasien, pegawai ruang operasi, atau lingkungan ruang operasi. Hal ini membuat kontaminasi bakteri semakin meningkat. ${ }^{10}$

Penggunaan sirkuit pernapasan anestesi yang semakin lama menyebabkan peningkatan kemungkinan pembentukan bakteri yang terkontaminasi oleh udara, yaitu suspensi bakteri yang bersumber dari sekresi tubuh yang terinfeksi maupun dari lingkungan dan membentuk koloni pada sirkuit pernapasan anestesi. Hal ini terjadi karena reaksi pada soda lime mesin anestesi membuat suasana sirkuit pernapasan anestesi menjadi hangat dan lembap. Suasana ini sangat ideal untuk pertumbuhan bakteri pada sirkuit pernapasan anestesi. ${ }^{7,15}$

\section{Simpulan}

Simpulan penelitian ini bahwa tidak ditemukan kontaminasi bakteri pada sirkuit pernapasan anestesi sebelum digunakan dan ditemukan kontaminasi bakteri pada sirkuit pernapasan anestesi sesudah digunakan di ruang operasi RSHS Bandung. Tidak ditemukan bakteri patogen di sirkuit pernapasan anestesi sesudah digunakan di ruang operasi.

\section{Daftar Pustaka}

1. Rees M, Sheraton TE, Modestini C, Wilkes AR, Hall JE. Assesing the efficacy of HME filters at preventing contamination of breathing systems. Anesthesia. 2007;62:67-71.

2. McGain F, Algie CM, O'Toole J, Lim TF, Mohebbi M. The microbiological and sustainability effects of washing anaesthesia breathing circuits less frequently. Anesthesia. 2014;69:337-42.

3. Hartmann D, Jung M, Neubert TR, Susin C, Nonnenmacher C. Microbiological risk of anaesthetic breathing circuits after extended use. Acta Anaesthesiol Scand. 2008;52:432-6.

4. Hubner NO, Daeschlein G, Lehmann C, Musatkin S, Kohlheim U. Microbiological safety and cost-effectiveness of weekly breathing circuit change in combanition with heat mositure exchange fiters: a prospective longitudinal clinical survey. GMS Krankenhaushygiene Interdisziplinar. 2011;6:1-6.

5. Spertini V, Borsoi L, Berger J, Blacky A, Magda. Bacterial contamination of anesthesia machines' internal breathingcircuit-systems. GMS Krankenhaushygiene Interdisziplinar. 2011;6:1-5.

6. Stackhouse RA, Beers R, Brown D, Brown M, Greene E, McCann ME, dkk. Recommendations for infection control for the practice of anesthesiology. Edisi ke-3. United States: American Society of Anesthesiologists; 2008.

7. Arai LA, Azevedo RB. Contamination of anesthesia circuits by pathogens. Rev Bras Anestesiol. 2011;61:50-9.

8. Kramer A, Kranabetter R, Rathgeber $\mathrm{J}$, Zuchner $\mathrm{K}$, Assadian 0 . Infection prevention during anesthesia ventilation 
by the use of breathing system filters (BSF): Joint recommendation by German Society of Hospital Hygiene (DGKH) and German Society for Anesthesiology and Intensive Care (DGAI). GMS Krankenhaushygiene Interdisziplinar. 2010;5:1-15.

9. Baillie JK, Sultan P, Graveling E, Forrest C, Lafong C. Contamination of anaesthetic machines with pathogenic organism. Anaesthesia. 2007;62:1257-61.

10. Scott DHT, Fraser S, Willson P, Drummond GB, Baillie JK. Passage of pathogenic microorganisms through breathing system filters used in anaesthesia and intensive care. Anaesthesia. 2010; 65:670-3.

11. El-Karadawy S, Helaly GF. Efficacy of the iso-gard high efficiency particulate airborne (HEPA) light breathing filter in preventing cross contamination through anesthesia breathing circuits. AJAIC. 2005;8:42-8.

12. Juwarkar CS. Cleaning and sterilisation of anaesthetic equipment. IJA. 2013;57:54150.

13. Paulsen AW. Cross-contamination via anesthesia equipment. Newsletters Spring. 2009:1-2.

14. Parwati I, Turbawaty DK, Sugianli AK. Peta bakteri dan kepekaannya terhadap berbagai antibiotika di rumah sakit umum pusat Dr. Hasan Sadikin semester II- tahun 2013. Bandung: SMF/Departemen Patologi Klinik RSUP Dr. Hasan Sadikin; 2013.

15. Morgan GE, Mikhail MS. Murray MJ. Clinical anesthesiology. Edisi ke-4. USA: McGrawHill Education; 2006. 